\title{
SPATIAL DISTRIBUTION OF THE MACROZOOBENTHOS IN THE SOLÍS GRANDE STREAM ESTUARY (CANELONES-MALDONADO, URUGUAY)
}

\author{
MUNIZ, P. and VENTURINI, N. \\ Sección Oceanografía, Facultad de Ciencias, Iguá 4225, Montevideo, Uruguay \\ Correspondence to: Pablo Muniz, Instituto Oceanográfico, USP, Praça do Oceanográfico, 191, \\ CEP 05508-900, Cidade Universitária, São Paulo, SP, Brazil, e-mail: pmmaciel@usp.br \\ Received April 17, 2000 - Accepted July 18, 2000 - Distributed August 31, 2001
}

(With 5 figures)

\begin{abstract}
The analysis of 24 quantitative macrobenthic samples taken from the Solís Grande Stream estuary yielded 10 species from a total of 4,446 individuals. It was verified that both species richness and diversity was lower than those recorded in nearby regions with similar environmental conditions. In contrast with other studies, a marked dominance of any of the present species was not verified. All the species recorded correspond to typical estuarine organisms. Abundance data were analysed with multivariate techniques and the results showed a relationship with salinity, mean diameter and the percentage of fine sand. According to the cluster analysis and the canonical correspondence analysis (CCA) four groups of stations were defined. The partition out of total variation of the species data showed that the amount of variation explained by the space alone was low. Spatial patterns observed and their possible causes are analysed and discussed in relation to the natural factors that acts in this coastal ecosystem.
\end{abstract}

Key words: macrobenthos, soft-bottom, temperate estuary, Uruguay.

\section{RESUMO}

\section{Distribuição espacial de macrozoobentos no estuário do Arroio Solís Grande (Canelones-Maldonado, Uruguai)}

A análise de 24 amostras quantitativas de macrobentos do estuário do Arroio Solís Grande revelou 10 espécies e um total de 4.446 organismos. A riqueza de espécies e a diversidade foram menores do que as registradas em regiões vizinhas com características ambientais similares. Em contraste com outros estudos, não se verificou grande dominância de nenhuma das espécies presentes. Todas são organismos tipicamente estuarinos. Os dados de abundância foram tratados com técnicas estatísticas multivariadas e os resultados mostraram relação com a salinidade, o diâmetro médio e a porcentagem de areia fina do sedimento. Tanto a análise de agrupamento quanto a análise de correspondência canônica (CCA) revelaram quatro grupos de estações dentro do estuário. A análise de divisão da variação total dos dados mostrou que a variabilidade em decorrência do espaço foi baixa. Os padrões espaciais observados e suas possíveis causas são analisados e discutidos em relação aos fatores naturais que atuam nesse ecossistema costeiro.

Palavras-chave: macrobentos, fundos inconsolidados, estuário temperado, Uruguai.

\section{INTRODUCTION}

In the last years coastal ecosystems have been object of particular attention. Among them, estuarine systems are zones of great importance, not only for the aquatic proper species of mixo- haline environments, but also for marine species which penetrate them. These systems are adequate environments for the reproduction, nursing and feeding of at least one stage of the life-cycle of certain species of fishes and invertebrates with a high commercial value (Miller \& Dunn, 1980). 
The benthic fauna is a very important linker within the estuarine ecosystem, depending greatly on the input of food (plankton and/or detritus) from the pelagic system and serving as a source of food for a variety of predators such as fishes, birds and human beings (Meire, 1994).

The description of spatial abundance patterns of benthic organisms, is an essential tool in ecological studies concerning the benthic fauna due to the observed patterns constitute the base for the construction of models, the development of hypothesis and to test these hypothesis experimentally. Thus, the observation of these patterns gives to us the context for the interpretation of experimental ecology results.

The distribution of organisms in an estuarine ecosystem depends on a special characteristic: the spatial and temporal heterogeneity of its physical factors.

The heterogeneity in the salinity distribution and in water circulation within an estuary is determined by the fresh water flow and the tides (Hansen \& Rattray, 1966). Fresh water is mixed with seawater, producing a gradient of salinity along all spatial axes.

The gradient of salinity is not equal in all estuaries. Its structure depends firstly on the relationship between the volume of water discharged by the river and the volume of sea water moved into the coast by tides and/or winds. Secondly, the gradient of salinity depends on the shape and the size of the estuary. The combination of both factors makes that each estuary had its own salinity pattern.

The distribution of bottom sediments is also heterogeneous. They are transported down estuary by the drainage flow and up estuary by tidal forces. When each one of the forces are small the deposition of sediments occurs. In general, those sediments of marine origin (sands) are found towards the estuary mouth and those of fluvial origin (silt and clay) are situated in the upper estuary. There are areas of the estuary (generally the centre) in which sediments suffer periods of suboxia or anoxia, limiting the distribution of benthic populations of aerobic breathing. In other systems was demonstrated that the distribution of benthic populations is highly dependent on sediment type, which is also correlated with the feeding type of these organisms
(Sanders, 1968; Jaramillo et al., 1984; López-Jamar \& Mejuto, 1985; Muniz \& Pires, 1999). Periodic anoxia leads to the colonisation of sediments by organisms of rapid growth and short life-time (Reiner, 1981). In estuaries however, this pattern of colonisation could be complicated by a salinity change faced in a different way by different organisms. Those individuals able to survive in environments with variable osmotic pressures, called eurihaline organisms, are submitted to positive selection. In almost estuaries a progressive decline in species number towards a salinity of 4 PSU is observed (McLusky, 1989). Other important characteristic is the great biomass of the few species present in an estuary. The reduction of possible competitors together with the abundance of food, permit to find in estuaries, populations of bivalves, crustaceans and polychaetes, bigger than those present in pure marine or freshwater environments (Levinton, 1982; Teal, 1962).

The study of coastal and estuarine ecosystems has been growing during the last years due to they have been strongly modified and influenced by human activities. Nowadays this human influence in the Solís Grande Stream estuary is still very incipient.

In Uruguay, there are many littoral inlets and lagoons that generally communicate with the open sea by more important or less important tributaries. In addition, the littoral of the Río de la Plata like the littoral of the Atlantic Ocean receives inputs of many tributaries with different flow. In spite of this fact, the studies performed until now are really scarce. We can cite the one made by Chebataroff $(1969,1973 a$, b, 1983), who studied and analysed morphologically general aspects of the fauna and flora of swamps, including considerations about the Santa Lucía River and the Pantanoso, Pando, Solís Grande, Maldonado and Valizas streams.

In relation to benthic studies, González (1980), Montero et al. (1983), Lucchi et al. (1983) analysed the benthic macro fauna and specially the population of Uca uruguayensis on the banks of the Solís Grande Stream.

The purpose of this study was to know quantitatively the sub littoral benthic communities of the Solís Grande Stream estuary and to relate their distribution with the surrounding physical environment in a spatial scale. 


\section{MATERIAL AND METHODS}

\section{Study area}

The Solís Grande Stream (Fig. 1) is situated in the southeast littoral of Uruguay between the $34^{\circ} 22^{\prime} 26^{\prime \prime}$ ' and $34^{\circ} 47^{\prime}$ '52' of south latitude and bet-

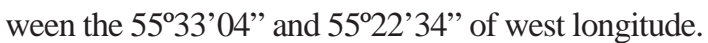
It is an important component of a permanent running system of the country called "Vertiente del Río de la Plata". The area of its basin has approximately $1,409 \mathrm{~km}^{2}$ (Jackson, 1979). From its beginnings to its mouth, crosses perpendicularly to the coastline an extension of $90 \mathrm{~km}$, receiving inputs of very permanents and non-permanents watercourses.

The mouth of the Solís Grande Stream is situated in a mixing (marine-fluvial) zone of the Río de la Plata, which is considered a transitional zone (Nagy, 1983; Poplawski, 1983).

The region where the present study was carried out corresponds approximately to the last $10 \mathrm{~km}$, and according to Jackson (1984), it constitutes the limit between a sedimentary plain and hills, recovered with conglomerates pertaining to the Cenozoic. Areas liable to flooding with similar characteristics to saline swamps (with the presence of Spartina alterniflora, Juncus acutus and Chasmagnatus granulata) and alluvial plains also exist in this region. In the area mentioned above, the Solís Grande Stream receives inputs of non-permanents watercourses which drain from swamping zones, making the stream to increase its width towards its mouth. The presence of sand dunes and littoral chains of hills produce in the stream mouth narrowness with the consequent effect of "piping" and the increment of the flow velocity (Unesco/MTOP, 1980). This narrow channel possess in its east bank wide sand dunes. In the mouth "the sand arrows system", a common feature of the streams and rivers of the uruguayan coast, is present but in the case of the Solís Grande Stream do not prevent a constant communication with the Río de la Plata (Jackson, 1984).

\section{Data collection}

Sediment samples were collected during October, 1995, in 24 points, distributed systematically along 3 longitudinal lines parallel to the stream banks and 8 transversal transects from the mouth to near $10 \mathrm{~km}$ upstream (Fig. 1). To each transversal transect corresponded three sampling sites. In order to verify the occurrence of a gradient of salinity the longitudinal axis was chosen. The transversal axis instead, was chosen to take into account the sediment variations observed in the preliminary sampling carried out in August of the same year.

In each sampling station, three replicates of sediment were collected using a Petersen dredge with $0.0517 \mathrm{~m}^{2}$ of sampling surface. The sediment collected was carefully washed and sieved through a $0.5 \mathrm{~mm}$ mesh and the material retained in the sieve was preserved in $70 \%$ ethanol. Approximately 100 grams of the sediment collected were used for granulometric and organic matter analyses. Granulometric analyses were done by the sieve and pipette techniques described by Suguio (1973), obtaining the statistical parameters of Folk \& Ward (1957). The percentages of silt, clay and the different sand fractions were also determined. The separation of the different fractions of sand is justified by the fact that some benthic species are very selective in relation to sediment grain size (Muniz \& Pires, 2000). The percentage of organic matter was calculated following the calcination method $\left(480^{\circ} \mathrm{C} / 2\right.$ hours $)$ described in Byers et al. (1978). In the laboratory the biological material was washed again, sorted, identified and quantified under a stereoscopic microscope. In each of the 24 sampling stations, measures of temperature and salinity were obtained with a termosalinometer YSI-85 and the depth was measured with a Leza sounder.

\section{Data analyses}

The frequency of occurrence of benthic species was calculated using the $\mathrm{F}$ index described by Guille (1970): $F=p_{a} / P \times 100$, where: $p_{a}=$ is the number of stations where the species a occurred and $\mathrm{P}$ is the total number of stations. Using this formula the species were classified in: constant species $(\mathrm{F}>50 \%)$, common $(10 \%<\mathrm{F}<49 \%)$ and rare species $(\mathrm{F}<10 \%)$.

The density of organisms and species was estimated and expressed as the mean number of individuals in $0.0517 \mathrm{~m}^{2}$. The Shannon-Wiener index (Shannon \& Weaver, 1963) was used to calculate the specific diversity $(\mathrm{H})$. As it was calculated using the logarithms in base 2 the data was expressed as bits/individuals. The evenness (J') was calculated with the Pielou index (1975) and the species richness (S) simply counting the number of species. All of the measures were expresed as the mean value of the three replicates. 


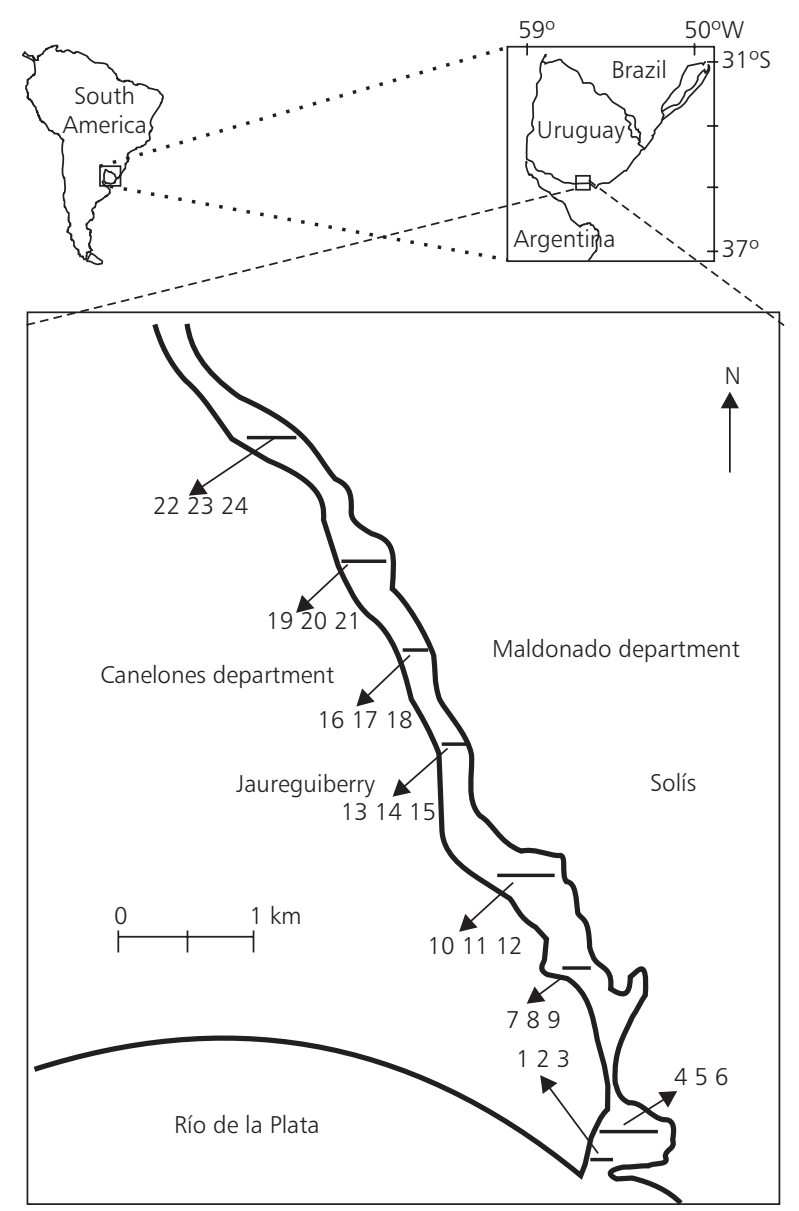

Fig. 1 - Map of the study area in Solís Grande Stream estuary showing the positions of the 24 sampling stations.

Biological data were also analysed with multivariate techniques of cluster analysis (classification in "Q mode"), using the quantitative dissimilarity coefficient of Bray-Curtis (1957) and the UPGMA method (Unweigthed Pair-Group Method Using Arithmetic Averages). The matrix and the dendrogram were calculated employing the computational program called Fitopac, developed by Dr. George Shepard of the State University of Campinas, SP, Brazil. In this case, the data was transformed using the $\log (\mathrm{X}+1)$ transformation in order to minimise the very high densities of some species. An ordination analysis was performed to assess the relationship between the environmental variables and the species distribution. The technique employed was a CCA (Canonical Correspondence Analysis) (Ter Braak, 1986, 1988) which tests statistically if the environmental variables are related to the species distribution, by means of the Monte-Carlo test (Ter Braak, 1990) using the forward selection option. The Monte-Carlo permutation test substitutes the $\mathrm{F}$ test or the $\mathrm{t}$ test used in the multiple regression. The purpose of the selection of environmental variables is to find out a minimal set of variables that explain the species data about as well as the full set. The program employed was the Canoco (Ter Braak, 1986, 1988). This method of ordination has some advantages relative to other techniques. One of them is that it focuses on the relationships between the species, the sampling stations and the environmental variables considered, permitting in this way, an automatic interpretation of ordination axes (Ter Braak, 1986). Other advantage is that it permits to know which species are influenced by each one of the variables measured. It combines aspects of a regular ordination with those of a regression. The biological matrix was the same used for the classification analysis. Before the analysis, the environmental matrix was standardised employing the 
following formula: $\mathrm{Y}=\left(\mathrm{X}-\mathrm{X}_{\mathrm{m}}\right) / \mathrm{S}_{\mathrm{x}}$, where $\mathrm{Y}$ is the standardised variable, $\mathrm{X}$ is the non standardised variable, $X_{m}$ is the mean value of $X$ and $S_{x}$ is the standard deviation of $X$.

Because some species and environmental variables may share a common spatial structuring (spatial autocorrelation), whose interaction often results in an overlaid effect in space, it is interesting to know the relative contribution of these two different factors to the spatial heterogeneity observed. Then, in order to measure the fraction of the variation in the species matrix explained either by the environmental variables alone or the spatial structure of the species data alone, we constructed a "spatial matrix" and performed partial constrained ordinations (Ter Braak, 1988). This method consists in performing a canonical correspondence analysis (CCA) after removing, by multiple regression the effects of known or undesirable variables, called covariables (Borcard et al., 1992). We constructed a binary spatial matrix with 24 rows (corresponding to the 24 sampling stations) and 8 columns (corresponding to the eight transects).

\section{RESULTS}

\section{Environmental data}

Salinity data showed the existence of a gradient towards the mouth of the stream, with salinity values from 2.6 PSU (St. 24) upstream to 32.0 PSU (St. 1) in the mouth (Fig. 2). The temperature was homogeneous along the area of study varying between 18 and $23^{\circ} \mathrm{C}$ (Fig. 2). Bottom sediments varied from silt to coarse sand, predominating the former in the stations corresponding to the medium section of the stream. Generally, the sediments showed from a moderate to a very good selection. The organic matter content varied from 0.75 (St. 22) to 3.45 (St. 4) (Fig. 2).

\section{Fauna}

A total of 4,446 individuals distributed in only 10 macrobenthic species were recorded. Mean densities varied from 1 to 284 ind./0.0517 $\mathrm{m}^{2}$. The polychaete Nephtys fluviatilis and the bivalve Erodona mactroides, were classified according their frequency of occurrence as constant species. Four species (an amphipod not identified, Tagelus plebius, Heleobia cf. australis and Heteromastus similis) were classified as common and the remaining four (Cyrtograpsus angulatus, Neanthes succinea,
Ficopomatus enigmaticus and Kalliapseudes schubarti) as rare species (Table 1). As a general trend, densities were higher in silt and sand-silt bottom sediments. Diversity was low, varying from 0 bits/ind (St. 17 to 24) where only E. mactroides occurred to 1.32 bits/ind (St. 3 and 7) (Fig. 2). The species richness, measured as the number of present species varied between 1 and 5, coinciding the higher values with the higher values of diversity (Fig. 2).

\section{Multivariate analysis}

Classification: The results of the cluster analysis in Q mode are resumed in Fig. 3. At the 50\% of dissimilarity we can observe four different situations. The first group (1), includes only station 14 which is situated in the medium longitudinal line and corresponds to the channel of the streambed. In it, the serpulid polychaete Ficomastus enigmaticus appeared and silt and coarse sand predominate in the sediments. The second group (2) is form by stations 1 to 9 and station 15 . Sediments were poorly selected predominating the fine sand. All stations have in common the high abundance of Heteromastus similis, Tagelus plebius, Kalliapseudes schubarti, Nephtys fluviatilis and an amphipod not identified. Stations 16 to 24 are clustered in the third group (3) by the single presence of the bivalve E. mactroides. Finally, the fourth group (4) is formed by stations 10, 11, 12 and 13 which have in common the high abundance of the polychaete $N$. succinea, the gastropod Heleobia cf. australis, and the brachiura Cyrtograpsus angulatus. Coarse silt together with the highest percentages of organic matter are also common characteristics of these stations.

Ordination: Basically, the same groups obtained with the classification analysis were also obtained with de CCA (Fig. 4). Correlation coefficients between the species distribution and the environmental variables were 0.91 for axis 1 and 0.74 for axis 2. The Monte-Carlo permutation test showed a significant relationship ( $\mathrm{p}<0.001$ ) between the species distribution and the environmental variables selected with the forward option.

These environmental variables were, mean sediment diameter (MD), salinity (UPS), percentage of fine sand (FS), percentage of medium sand (MS) and organic matter content (OM). Only the first two axes were represented, because they explained $61.4 \%$ of the variance of the weighted averages, (39\% and $22.4 \%$, respectivelly). 
The sum of all canonical eigenvalues was 1.671, the eigenvalue for axis one was 0.763 and for axis two 0.441 .

Table 2 shows the interset correlations of the selected environmental variables with the first two axes.
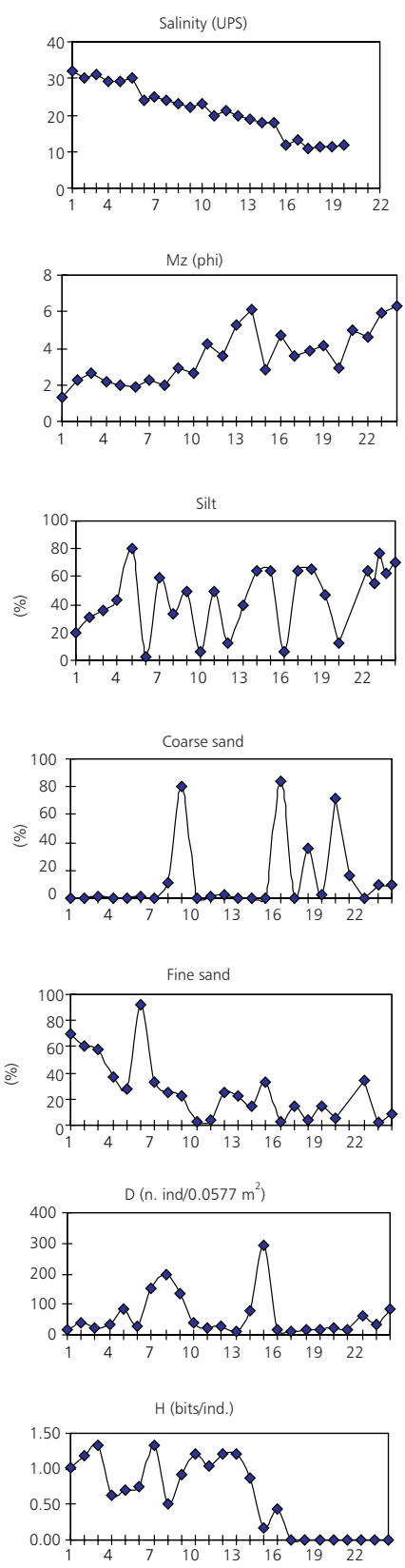

Variation partition: The four analyses made to partialling out the spatial variation in species data gave the following results:

1. CCA of the species matrix, constrained by the environmental matrix: sum of all canonical eigenvalues $=1.671$.
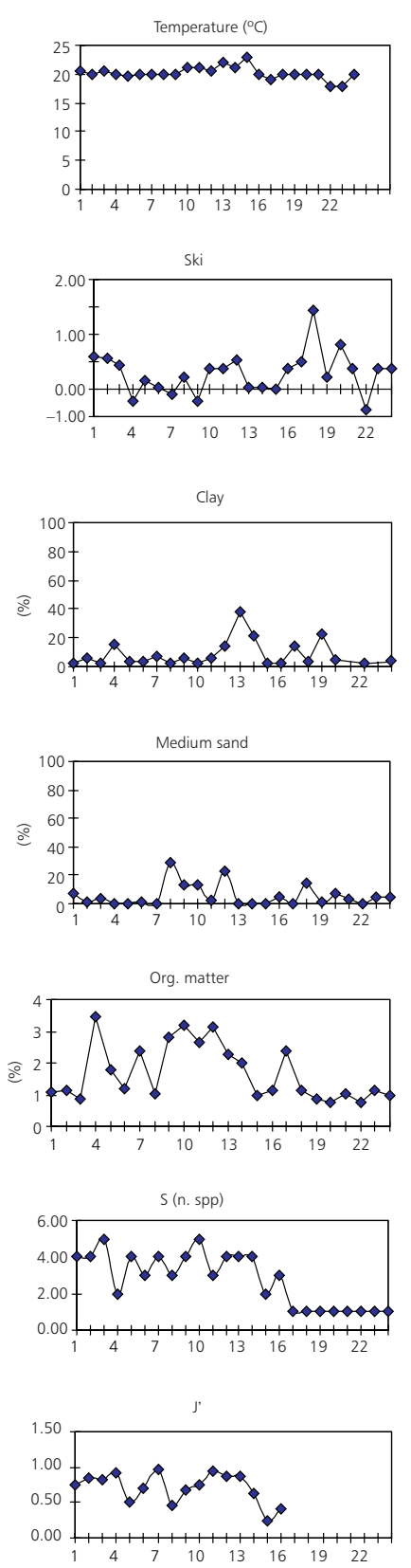

Fig. 2 - Values of the environmental variables studied, density (D), species richness (S), diversity (H) and eveness $\left(\mathrm{J}^{\prime}\right)$ in the 24 sampling stations along the Solís Grande Stream estuary. 
TABLE 1

Macrobenthic species with their respectives values of frequency (FO) (Guille, 1970), their clasification and mean abundance for the study area.

\begin{tabular}{|l|c|c|c|}
\hline \multicolumn{1}{|c|}{ Species } & FO $(\boldsymbol{\%})$ & FO & Mean abundance \\
\hline Amphidpodo n.i & 11.1 & common & 22 \\
\hline Cyrtograpsus angulatus & 7.4 & rare & 2 \\
\hline Tagelus Plebius & 18.5 & common & 35 \\
\hline Erodona mactroides & 66.7 & constant & 310 \\
\hline Heleobia cf. australis & 37 & common & 73 \\
\hline Neanthes succinea & 7.4 & rare & 5 \\
\hline Nephthys fluviatilis & 59.3 & constant & 524 \\
\hline Ficopomatus enigmaticus & 3.7 & rare & 59 \\
\hline Kalliapseudes schubarti & 7.4 & rare & 13 \\
\hline Heteromastus similis & 37 & common & 439 \\
\hline
\end{tabular}

2. CCA of the species matrix constrained by the spatial matrix: sum of all canonical eigenvalues $=0.514$.

3. CCA of the species matrix, constrained by the environmental matrix, after removing the effect of the spatial matrix: sum of all canonical eigenvalues $=1.37$.

4. CCA of the species matrix constrained by the spatial matrix, after removing the effect of the environmental matrix: sum of all canonical eigenvalues $=0.21$.

The total inertia was 2.226 then, the percentage of the total variation of the species matrix accounted for step (1) was: $75.07 \%$, for step (2): $23.09 \%$, for step (3): $61.5 \%$ and for step (4): $9.43 \%$. The overall amount of explained variation was $84.5 \%$ and the whole variation of the species matrix can be partioned as follows.

The amount of total variation of the species matrix accounted for space alone was $9.43 \%$, the amount of variation explained by environmental variables alone was $61.5 \%$, the spatially structured environmental variation (Env + space) was $13.57 \%$ and the undetermined variation was $15.5 \%$ (Fig. 5).

\section{DISCUSSION}

The salinity values recorded showed the existence of a saline gradient depart from the mouth of the stream. The continuous opening of the sand bar situated at the mouth, permits a constant communication between the brackish water of the Río de la Plata and the Solís Grande Stream.

The effects of the entry of this brackish water were observed in the salinity values recorded in this study. In relation to sediments the variation did not show a defined pattern. In some stations, there are banks muddy sediments which increase their size towards the central zone of the stream. The presence of this coarser material in some zones of the channel, could be determined by the transport capacity of the stream and by the existence of ravines and terraces in its banks that would be contributing with this material.

In addition to this, the tidal wave that reduces the outflow velocity of the stream water could favour the deposition of fine sediment fractions, especially silt and clay (Unesco/MTOP, 1980). This fact was better observed in the lower part of the stream course. Wide swamping zones existing in this region could also act as traps of suspended fine material. In areas of smooth slope when an increase in water level occurs, the vegetation of their banks (Spartina alterniflora and Juncus acutus) could promote the deposition of sediments and in consequence the stabilisation of the bottom (Green, 1968).

Generally, stream sediments are constituted of many size classes, from coarse to very fine grains. In the Solís Grande Stream, a superficial fine layer of mud was always observed over sandy deposits. 


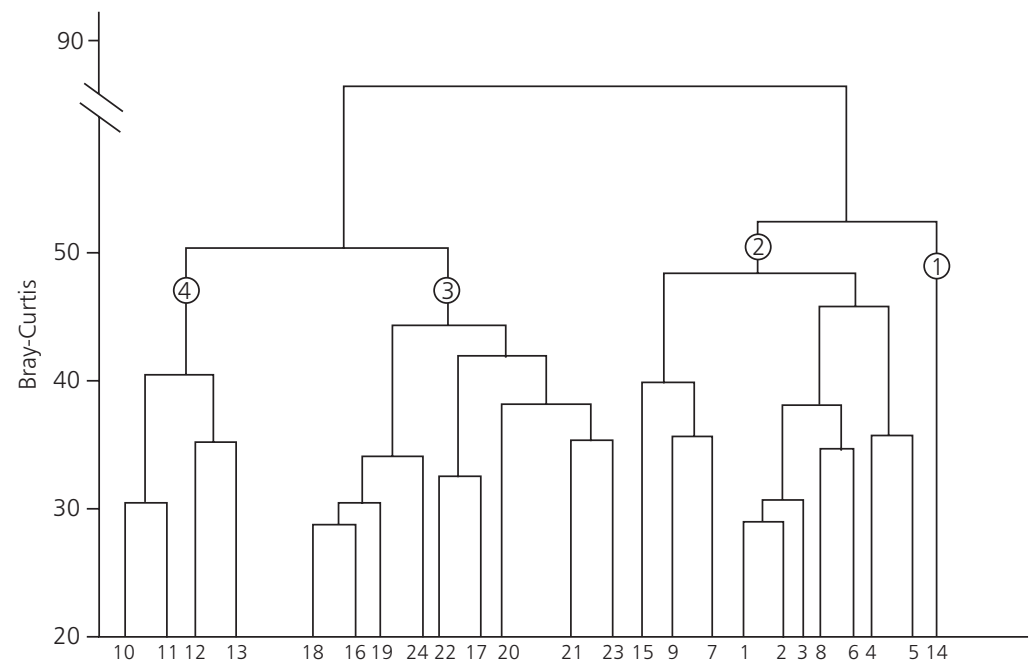

Fig. 3 - Dendrogram showing the result of the cluster analysis in $Q$ mode. The sample stations are the numbers in the $\mathrm{X}$ axis. The numbers correspond to the four groups formed by this technique.

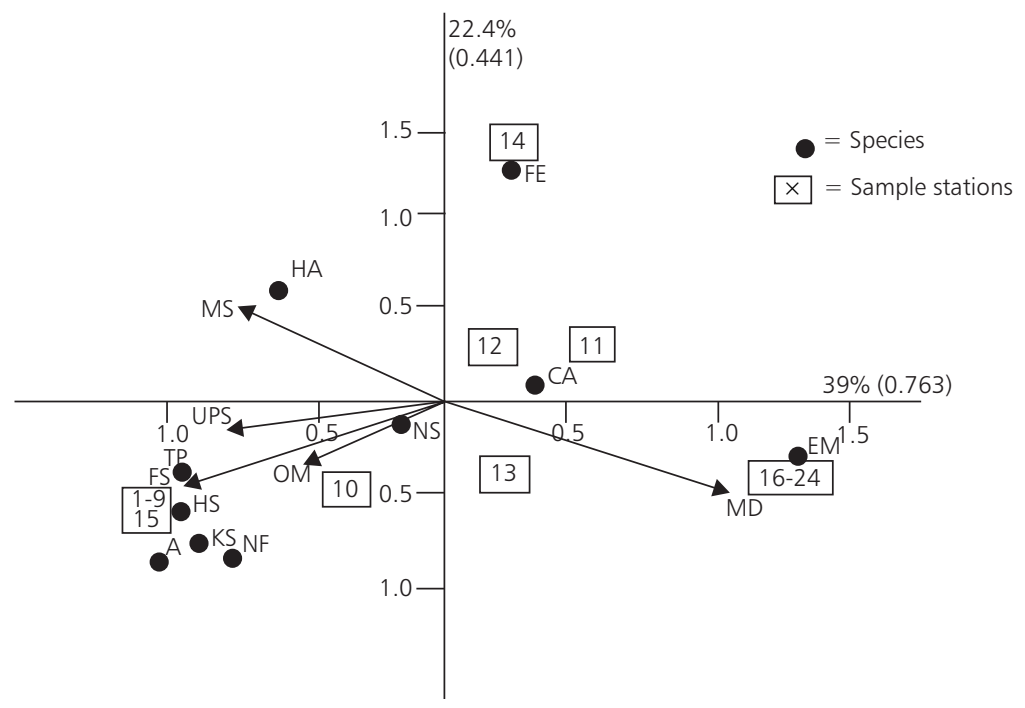

Fig. 4 - Ordination diagram obtained from the canonical correspondence analysis (CCA), showing the main groups formed, the percentage of the total variation and the eingenvalues of the first two axes are indicated. FS = fine sand content; MS = medium sand content; UPS = salinity; OM = organic matter content; $\mathrm{MD}=$ medium diameter of the sediment; $\mathrm{FE}=$ Ficopomatus enigmaaticus $; \mathrm{CA}=$ Cyrtograpsus angulatus $; \mathrm{EM}=$ Erodona mactroides $; \mathrm{TP}=$ Tagelus plebius $; \mathrm{NF}=$ Nephtys fluviatilis; $\mathrm{KS}=$ Kalliapseupes schubarti; $\mathrm{HS}=$ Heteromastus similis; HA = Heleobia cf. australis; NS = Neanthes succinea; $\mathrm{A}=$ amphipod not identified.

According to Suguio (1973), processes of flocculation and sedimentation produced by the input of brackish water together with the low flow conditions that permit sedimentation, could be responsible of this fact. Once deposited these organic particles would formed a mucous material typical of estuarine bottoms.
The permanence of this layer could be determined by the prevalent hydrodynamical conditions but in general is very persistent and only strong water movements or events of bioturbation could dislocate it. A great abundance of valves of molluscs, especially of Erodona mactroides and Tagelus plebius, was observed in the medium 
region of the area studied. In the opinion of Borges da Costa (1971), these calcareous elements and the organic matter debris are characteristics of estuarine sediments.

The organic matter content in the sediments was high, being within the range recorded by other authors for estuarine systems of similar latitudes (Seys et al., 1994; Ieno \& Bastida, 1998; Muniz et al., 2000). Spartina sp. that is considered an important organic matter producer in shallow coastal areas (Netto \& Lana, 1997) was present in our study region.

The macrobenthic specific composition of the Solís Grande Stream results to be similar to the existing in other mixohaline biotopes of nearby regions (Benvenuti, 1997; Capitoli et al., 1978; Lana et al., 1989; Monro, 1937; Orensanz \& Estivariz, 1971; Olivier et al., 1972; Ieno \& Bastida, 1998; Muniz et al., 2000; Scarabino et al., 1975). All species found are typical of estuarine environments. Although the absence of some species that are present in nearby regions, studied by the authors named above, is important to remark the similarity at the specific level, which would be demonstrating the existence of an estuarine biota within the same biogeographic province.

Species richness and diversity were low for all the studied area and the values are similar to those recorded by the authors mentioned before. Estuaries are subject, in addition to the anthropogenic pressure, to periodic natural perturbations that result in lesser diversity and specific richness values than more stable environments. Many authors (see for example Benvenuti, 1997) had denoted, that these communities are characterised by great quantitative fluctuations in the abundance of many of their species but showed a higher qualitative persistence. For this reason, we could expect that this relative low specific richness remains in temporal scale. Diversity was clearly determined by the species richness and the evenness, both showing the same behaviour.

This means that when the species number increased, the individuals were more homogeneously distributed among the present species with none of the species having a marked dominance.

Density was variable. The great values corresponded to the inferior half of the studied region, excepting, the first transect next to the mouth of the stream, where the environmental energy is very high and creates less proper conditions for the survival of the organisms.

The cluster analysis, isolated station 14 which is situated in the centre of the stream. The CCA showed neither relationship between the environmental variables considered and this station, nor with the serpulid polychaete Ficomastus enigmaticus found only in this place. This polychaete, according to Olivier et al. (1972) is a constructor of calcareous tubes, it inhabits the centre channel of the Mar Chiquita Lagoon in which it has a suitable substrate (fossil shells and pebbles) to construct its tube. We could not explain the reason of the appearance of $F$. enigmaticus only in station 14, since rests of E. mactroides and T. plebius, the essential material for the construction of its tube, were also very abundant from station 10 to station 24, including stations 11, 17, 20 and 23 situated as St. 14 in the center channel of the stream.

The second group included stations 1 to 9 and station 15 corresponds in the CCA to the cluster formed by $H$. similis, $K$. schubarti, $N$. fluviatilis and T. plebius. This cluster is recognised as an association of frequent occurrence in estuaries of the South-eastern coast of Brazil (Lana, 1986; Lana et al., 1989; Benvenuti, 1997).

TABLE 2

Interset correlation values of environmental variables selected by the forward option with the first two axes.

\begin{tabular}{|c|c|c|}
\hline & Axis 1 & Axis 2 \\
\hline MD & 0.8823 & -0.2321 \\
\hline UPS & -0.6892 & -0.1074 \\
\hline FS & -0.7716 & -0.2243 \\
\hline MS & -0.7418 & 0.3487 \\
\hline OM & -0.3729 & -0.2582 \\
\hline
\end{tabular}




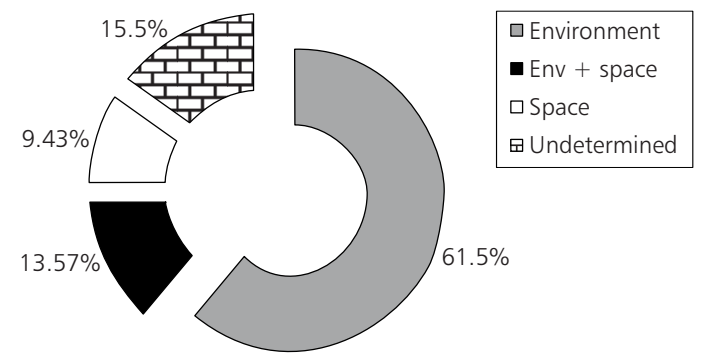

Fig. 5 - Variation partitioning of the macrobenthic fauna data matrix.

These species have a reduced mobility, they are within tubes and/or galleries in environments from low to moderate energy and with good availability of organic matter. Benvenuti (1997) observed that the greatest densities of these species occur in summer and in autumn, coinciding with their reproductive periods, this could explain the not much high densities recorded in this study. The group of species cited above was clearly related with the percentage of fine sand in the sediments (Fig. 4).

In those stations where sediment heterogeneity was greater (poor selection), all the species of this group were classified as common (sensu Guille, 1970) with the exception of the polychaete N. fluviatilis which had a wide spatial distribution. Benvenuti (1997) also marks that this species in "de los Patos" Lagoon shows a wide distribution and a temporal constancy. Orensanz \& Estivariz (1971) found this polychaete in all the Mar Chiquita Lagoon (Argentina), remarking its presence in very muddy bottoms.

The third group obtained includes stations 16 to 24 and corresponds to the upper region of the area studied. It can be seen in the CCA, that these stations have in common the presence of the bivalve $E$. mactroides which, although be consider a constant species (sensu Guille, 1970) occurred only in these stations. Many authors had remarked its presence in diverse estuarine environments of the Río de la Plata and the Atlantic Ocean (Scarabino et al., 1975; Capitoli et al., 1978; Benvenuti et al., 1978; Muniz et al., 2000). Moreover, its capacity to colonise limnic environments that receive periodical inputs of brackish water is known (Benvenuti et al., 1978). In the Solís Grande Stream, E. mactroides was a typical species of the upper region (Sts. 16 to 24) where the salinity was lower than 15 PSU. In this study, this species does not have any particular preference of any particular sediment type. This fact, was observed by other authors who suggest that this bivalve inhabits, from sandy to muddy sediments types (Benvenuti et al., 1978; Nion, 1979).

Finally, the fourth group obtained in the cluster analysis matches with the species and stations situated in the centre part of the CCA diagram. These stations, corresponding to the central region of the studied area have in common the presence of Heleobia cf. australis, Neanthes succinea and the brachiura Cyrtograpsus angulatus. These stations, presented a high organic matter content and the predominance of coarse silt sediments. Heleobia $\mathrm{cf}$. australis is a small deposit-feeding gastropod, widely distributed in estuarine environments of the uruguayan coastal zone (Scarabino et al., 1975) and which generally inhabits muddy bottoms with high organic content (Muniz et al., 2000). The polychaete $N$. succinea is considered widely distributed in marine environments inhabiting hard or soft substrates (Fauchald \& Jumars, 1979). This polychaete also shows a great feeding plasticity (Muniz \& Pires, 1999). The placement of these species in the centre of the ordination diagram, is indicating their non-selectivity for any of the sedimentological variables studied.

Ecological phenomena are explained by nonmutually-exclusive abiotic and biotic processes that overlap in space and time (Quinn \& Dunham, 1983). According to Legendre (1993), spatial autocorrelation, which comes either from physical forcing of environmental variables or for community processes such as competition and predation, presents a problem for statistical testing because autocorrelated data violate the assumption of independence of most standard statistical procedures. In order to make a valid use of these standard statistical procedures, 
we partitioned out the total variation of the species data and estimated the amount accounted for space alone. In our study, the amount of total variation of the species matrix accounted for space alone was 9.43\%. According to Borcard et al. (1992), this small amount shows that no fundamental spatial structuring process has been missed and therefore, the standard statistical procedures applied are valid.

In summary, the spatial distribution patterns of the sublitoral macrofauna of Solís Grande estuary seems to be determined by the hydrodynamic conditions that influence the salinity and by some sedimentary characteristics such as the percentage of fine sand. Diversity and species richness were low, but in contrast with other studies, a marked dominance of any of the present species was not found. The species present, correspond to typical estuarine organisms also recorded in estuarine ecosystems of nearby regions.

Acknowledgments - Special thanks to the Comisión Sectorial de Investigación Científica (CSIC/Uruguay), for giving partial financial support to this work. Also are acknowledge the colleagues of the Oceanography Section of the Faculty of Sciences for their help in field and laboratory work, specially A. Carranza, M. Rodríguez and B. Yaniccelli.

\section{REFERENCES}

BENVENUTI, C. E., 1997, Benthic invertebrates. In: U. Seeliger, C. Odebrecht \& J. P. Castello (eds.), Subtropical convergence marine ecosystem. The coast and the sea in the warm temperate Southwestern atlantic. Springer Verlag, Heidelberg, New York, pp. 43-46.

BENVENUTI, C. E., CAPITOLI, R. R. \& GIANUCA, N. M., 1978, Estudos de ecologia bentônica na região estuarial da Lagoa dos Patos. II. Distribuição quantitativa dos macrobentos infralitoral. Atlântica, 3: 23-32.

BORCARD, D., LEGENDRE, P. \& DRAPEAU, P., 1992, Partialling out the spatial component of ecological variation. Ecology, 73(3): 1045-1055.

BORGES DA COSTA, C. M., 1971, Importância paleoecológica e estratigráfica de Erodona mactroides Dauvin (Mollusca, Bivalvia). Iheringia Geologia, 4: 3-18.

BRAY, J. R. \& CURTIS, J. T., 1957, An ordination of the upland forest communities in southern Wisconsin. Ecol. Monogr., 27: 325-349.

BYERS, S. C., MILLS, E. L. \& STEWART, P. L., 1978, A comparison of methods to determining organic carbon in marine sediments, with suggestion for a standard method. Hidrobiologia, 58: 37-43.

CAPITOLI, R. R., BENVENUTI, C. E. \& GIANUCA, N. M., 1978, Estudos de ecologia bentônica na região estuarial da Lagoa dos Patos. I. Comunidades bentônicas. Atlântica, 3: 5-22.
CHEBATAROFF, J., 1969, Relieve y Costas. Nuestra Tierra, 3: 1-68.

CHEBATAROFF, J., 1973a, Ambientes salinos, su vegetación: problemas de utilización. Dpto. Geogr. Fac. Hum. Cienc., Montevideo, 5: 35.

CHEBATAROFF, J., 1973b, Introducción al estudio de los ecosistemas de bañados salinos. Rev. Urug. Geogr. Ser. 2, 2: 31-41.

CHEBATAROFF, J., 1983, Marismas y arenales marinos costeros del Plata y del Atlántico uruguayos. In: Resúmenes del VII Simposio Latinoamericano sobre Oceanografía Biológica, Uruguay, 180p.

FAUCHALD, K. \& JUMARS, P. A., 1979, The diet of worms: a study of polychaetes feeding guilds. Oceanogr. Mar. Biol. A. Rev., 17: 193-284.

FOLK, R. L. \& WARD, W. C., 1957, Brazos River bar: a study of the significance of grain size parameters. $J$. Sedim. Petrology, 27: 3-26.

GONZÁLEZ, L. A., 1980, Primera comunicación a un estudio morfológico y bioecológico de Uca uruguayensis Nobili, 1901. Rev. Fac. Hum. Ciencias, Uruguay, 1(1): 153-200.

GREEN, J., 1968, The biology of estuarine animals. Biology Series. Sidgwick \& Jackson, London, 401p.

GUILLE, A., 1970, Benthic bionomy of continental shelf of the french catalane coast. II. Benthic communities of the macrofauna. Vie Milieu, 21(8): 239-250.

HANSEN, D. \& RATTRAY, M., 1966, New dimension in estuary clasification. Limnol. Oceanogr., 11(3): 319-325.

IENO, E. N. \& BASTIDA, R. O., 1998, Spatial and temporal patterns in coastal macrobenthos of Samborombon Bay, Argentina: a case of study of very low diversity. Estuaries, 21(4B): 690-699.

JACKSON, M., 1979, Los aportes continentales al medio costero y de plataforma interior de la costa uruguaya. 11p. (Ms. unpublished)

JACKSON, M., 1984, Contributions to the geology and hidrology of South-eastern Uruguay based on visual satellite remote sensing interpretation. Münch. Geogr. Abhand. München, 31: 1-68.

JARAMILLO, E., MUSLOW, S., PINO, M. \& FIGUEROA, H., 1984, Subtidal benthic macroinfauna in an estuary of South Chile: distribution patterns in relation to type sediments. PSZN. Mar. Ecol., 5(2): 119-132.

LANA, P. C., 1986, Macrofauna bêntica de fundos sublitorais não consolidados da Baía de Paranaguá (Paraná). Nerítica, 1(3): 79-89.

LANA, P. C., ALMEIDA, M. V. O., FREITAS, C. A. F., COUTO, E. C. G., CONTI, L. M. P., GONZÁLEZPERONTI, A. L., GILES, A. G., LOPES, M. J. S., SILVA, M. H. C. \& PEDROSO, L. A., 1989, Estrutura espacial de associações macrobênticas sublitorais da Gamboa Perequê (Pontal do Sul, Paraná). Nerítica, 4(1/2): 119-136.

LEGENDRE, P., 1993, Spatial autocorrelation: trouble or new paradigm? Ecology, 74(6): 1659-1673. 
LEVINTON, J. S., 1982, Marine Ecology. Prentice-Hall, NJ, 526p.

LÓPEZ-JAMAR, E. \& MEJUTO, J., 1985, Bentos infaunal en la zona submareal de la ría de la Coruña. I. Estructura y distribución espacial de las comunidades. Bol. Inst. Esp. Oceanogr., 2(3): 99-109.

LUCCHI, C., GIORDANO, S. \& MONTERO, R., 1983, Crecimiento relativo en Uca uruguayensis Nobili, 1901. In: Resúmenes del VIII Simposio Latinoamericano sobre Oceanografía Biológica, Uruguay, 1: 133.

McLUSKY, D., 1989, The estuarine ecosystem. Chapman \& Hall, London, 215p.

MEIRE, P. M., 1994, Theme III: The structure of the benthic system. Hydrobiologia, 282/283: 153-156.

MILLER, J. M. \& DUNN, M. L., 1980, Feeding strategies and patterns of movements in juvenile estuarine fishes. In: V. S. Kennedy (ed.), Estuarine Perspectives, New York, Academic Press.

MONRO, C. C. A., 1937, On some fresh water polychaetes from Uruguay. Ann. Mag. Nat. Hist., 11(2): 311-314.

MONTERO, R., GIORDANO, S. \& LUCCHI, C., 1983, Estructura y densidad de las cuevas de Uca uruguayensis Nobili, 1901 (Decápoda, Brachyura). In: Resúmenes de las III Jornadas de Ciencias Naturales, Uruguay, 1: 52-59.

MUNIZ, P. \& PIRES, A. M. S., 1999, Trophic structure of polychaetes in the São Sebastião Channel (Southeastern Brazil). Mar. Biol., 134: 517-528.

MUNIZ, P. \& PIRES, A. M. S., 2000, Polychaetes associations in a subtropical environment (the São Sebastião Channel, SP, Brazil): a structural analysis. PSZN Mar. Ecol., 21(2): 145-160.

MUNIZ, P., VENTURINI, N. \& RODRÍGUEZ, M., 2000, Macrobenthic communities in a temperate urban estuary of high dominance and low diversity: Montevideo Bay (Uruguay). Mar. Biol. (in press).

NAGY, G., 1983, Caracterización de los procesos hidrológicos del Río de la Plata. Bachelor Thesis, Fac. Hum. Cienc. Uruguay, 267p. (unpublished).

NETTO, S. A. \& LANA, P. C., 1997, Influence of Spartina alterniflora on superficial sediment characteristics of tidal flats in Paranaguá Bay (South-eastern Brazil). Estuar. Coast. Shelf Sci., 44: 641-648.

NION, H., 1979, Zonación del macrobentos en un sistema lagunar litoral oceánico. Memorias del Seminario sobre Ecología Bentónica y Sedimentación de la Plataforma Continental del Atlántico Sur. Unesco, Montevideo, pp. 225-235.

OLIVIER, S. R., ESCOFET, A., PENCHASZADEH, P. \& ORENSANZ, J. M., 1972, Estudios ecológicos de la región estuarial de Mar Chiquita (Buenos Aires, Argentina). I. Las comunidades bentónicas. An. Com. Inv. Cient. Bs. As., 194(5-6): 237-262.
ORENSANZ, J. M. \& ESTIVARIZ, M. C., 1971, Los anélidos poliquetos de aguas salobres de la provincia de Buenos Aires. Rev. Mus. La Plata, Zool., 11(98): 95-114.

PIELOU, E. C., 1975, Ecological diversity. New York, John Wiley, 165p.

POPLAWSKI, R., 1983, Introducción al estudio de la variabilidad temporal de la salinidad en la costa uruguaya. Bachelor Thesis. Fac. Hum. Cienc. Uruguay, 131p. (unpublished).

QUINN, J. F. \& DUNHAM, A. E., 1983. On hypothesis testing in ecology and evolution. American Naturalist, 122: 602-617. In: D. BORCARD, P. LEGENDRE, \& P. DRAPEAU, 1992, Partialling out the spatial component of ecological variation. Ecology, 73(3): 10451055 .

REINER, S., 1981, Temporal patterns in the structure of macrobenthic communities of an Australian estuary. Estuar. Coast. Shelf Sci., 13: 597-620.

SANDERS, H. L., 1968, Marine benthic diversity: a comparative study. Am. Nat., 102(925): 243-281.

SCARABINO, V., MAYTÏA, S. \& CACHES, M., 1975, Carta binómica litoral del departamento de Montevideo. I. Niveles superiores del sistema litoral. Comunicaciones de la Sociedad Malacológica del Uruguay, 4(29): 117-129.

SEYS, J. J., MEIRE, P. M., COOSEN, J. \& GRAEYMEERSCH, J. A., 1994, Long-term changes (1979-89) in the intertidal macrozoobenthos of the Oosterschelde estuary: Are patterns in total density, biomass and diversity induced by the construction of the strom-surge barrier? Hydrobiologia, 282/283: 251-264.

SHANNON, C. E. \& WEAVER, W. W., 1963, The mathematical theory of communication. University of I1linois Press, Urbana.

SUGUIO, K., 1973, Introdução à sedimentologia. Edgard Blucher, São Paulo.

TEAL, J., 1962, Energy flow in the salt marsh ecosystem of Georgia. Ecology, 43(4): 614-624.

TER BRAAK, C. J. F., 1986, Weighted averaging, logistic regression and the Gaussian response model. Vegetatio, 65: 3-11.

TER BRAAK, C. J. F., 1988, Canoco: a fortram program for canonical community ordination by partial, detrended, canonical, correspondence analysis, principal components analysis and redundancy analysis. Version 2.1. Technical Report: LWA-88-02. Agricultural Mathematics Group, Wageningen, The Netherlands, 95p.

TER BRAAK, C. J. F., 1990, Updates notes: Canoco version 3.10. Copyright Agricultural Mathematics Group, Wageningen.

UNESCO/MTOP, 1980, Proyecto de Conservación y Mejora de Playas. 